\title{
PELATIHAN SELEKSI PENERIMAAN SISWA BARU PADA SMK TANJUNG BARAT DAN SMK PGRI 28 MENGGUNAKAN BAHASA PEMROGRAMAN JAVA
}

\author{
Andi Prastomo, Salman Alfarisi \\ Program Studi Informatika Fakultas Teknik, Matematika Dan Ilmu Pengetahuan Alam \\ Universitas Indraprasta PGRI. \\ andi_prastomo@ymail.com, salman.hotaru@gmail.com
}

\begin{abstract}
Abstrak
Perkembangan Ilmu Pengetahuan dan Teknologi (IPTEK) sangat pesat di era globalisasi saat ini. Pemanfaatan Teknologi informasi mencakup segala bidang diantaranya bidang pendidikan. Banyak sekolah sudah menerapkan teknologi informasi untuk membantu sistem berjalan mereka salah satunya sistem pendataan penerimaan siswa baru, akan tetapi tidak semua sekolah sudah menerapkannya misalnya SMK Tanjung Barat dan SMK PGRI 28. Kegiatan ini mengambil Judul "Pelatihan Seleksi Penerimaan Siswa Baru Pada SMK Tanjung Barat dan SMK PGRI 28 Menggunakan Bahasa Pemrograman Java ". pelatihan ini untuk memudahkan sekolah dalam melakukan pengelolaan data penyeleksian dan penerimaan siswa baru sehingga data-data tidak tercecer serta pengolahan data penerimaan siswa baru yang lebih baik dan terkomputerisasi sehingga lebih efektif dan efisien. Tujuan kegiatan adalah untuk memberikan pengetahuan dan pemahaman kepada para pengajar tentang cara penyeleksian dan penerimaan siswa baru dengan menggunakan aplikasi berbahasa pemrograman java, sehingga para panitia penerimaan siswa baru dapat lebih mudah dalam pengambilan keputusan mengenai penyeleksian penerimaan siswa baru.

Kata Kunci :Pelatihan, Penerimaan Siswa Baru, Java.
\end{abstract}

\begin{abstract}
The development of Science and Technology (Science and Technology) is very rapid in the current era of globalization. Utilization Information technology covers all areas including education. Many schools have applied information technology to help their system running one of them is new student admission data collection system, but not all schools have implemented such as SMK Tanjung Barat and SMK PGRI 28. This activity takes the title of "Pelatihan Seleksi Penerimaan Siswa Baru Pada SMK Tanjung Barat dan SMK PGRI 28 Menggunakan Bahasa Pemrograman Java ". this training to facilitate the school in managing data selection and acceptance of new students so that data is not scattered and processing data acceptance of new students better and computerized so that more effective and efficient. The purpose of the activity is to provide knowledge and understanding to the teachers about how to select and enroll new students using java programming language applications, so that the new admissions committee can more easily in decision making about the selection of new admissions.
\end{abstract}

Keyword: Training, Admissions, Java

\section{PENDAHULUAN}

Kemajuan ilmu pengetahuan dan teknologi suatu bangsa tentu tidak ter- lepas dari keberhasilan proses pembelajaran di lembaga-lembaga serta institusi-institusi pendidikan tinggi di negara tersebut. Tahapan perubahan diharapkan mampu membawa bangsa ke 
arah kemajuan peradaban yang lebih tinggi dan meresap secara utuh sebagai jati diri bangsa tersebut. Tingkat penguasaan ilmu dan teknologi merupakan bukti nyata keberhasilan pembangunan. Peningkatan penguasaan ilmu dan teknologi tidak hanya dilakukan pada pendidikan formal, namun juga dapat dilakukan melalui pendidikan nonformal. Menurut Undang-Undang No.20 Tahun 2003 Tentang Sistem Pendidikan Nasional dijelaskan pada Pasal 26 ayat 3: Pendidikan nonformal meliputi pendidikan kecakapan hidup, pendidikan anak usia dini, pendidikan kepemudaan, pendidikan pemberdayaan perempuan, pendidikan keaksaraan, pendidikan keterampilan dan pelatihan kerja, pendidikan kesetaraan, serta pendidikan lain yang ditujukan untuk mengembangkan kemampuan peserta didik. Hal mengenai pendidikan dan pelatihan kerja diperjelas pada ayat 5 "Kursus dan pelatihan diselenggarakan bagi masyarakat yang memerlukan bekal pengetahuan, keterampilan, kecakapan hidup, dan sikap untuk mengembangkan profesi, bekerja, usaha mandiri, atau melanjutkan pendidikan kejenjang yang lebih tinggi". Salah satu jenis pelatihan yang dimaksud adalah pelatihan keterampilan komputer. Pelatihan keterampilan komputer adalah serangkaian kegiatan yang memberikan kesempatan untuk mendapatkan dan meningkatkan keterampilan yang berkaitan dengan komputer.

Undang-Undang Nomor 20 Tahun

2003 tentang Sistem Pendidikan Nasional memberikan dasar hukum untuk membangun pendidikan nasional dengan menerapkan prinsip demokrasi, desentralisasi, otonomi, keadilan dan menjunjung tinggi hak azasi manusia. Penerapan ketentuan dalam undangundang ini diharapkan dapat mendukung segala upaya untuk memecahkan masalah pendidikan, guna memberi- kan sumbangan yang signifikan terhadap masalah-masalah makro bangsa Indonesia. Semua lapisan masyarakat terkait langsung maupun tidak langsung, baik sebagai konseptor maupun pengambil keputusan serta pelaksana dunia pendidikan diharapkan memiliki pemahaman tentang undangundang tersebut sehingga mampu memberikan makna dalam pengembangan pendidikan dalam rangka terciptanya sumber daya manusia Indonesia yang berkualitas.

Dalam penyajian informasi, setiap instansi memiliki cara yang berbedabeda pula. Ada yang sudah menggunakan komputer dan ada juga yang masih menggunaka cara manual. Hal ini terjadi karena dalam menggunakan komputer membutuhkan dana yang cukup mahal, selain faktor tersebut, brainware juga merupakan kendala serta kurangnya pengaruh eksternal yang masuk kedalam instansi tersebut.

Melihat banyaknya buku-buku yang digunakan dalam proses penerimaan murid baru pada SMK Tanjung Barat dan SMK PGRI 28, yang mengakibatkan pekerjaan menjadi tidak efisien, maka kami berkeinginan untuk mengadakan Pelatihan Seleksi Penerimaan Siswa Baru Mengunakan Bahasa Pemrograman Java sehingga dapat memberikan kemudahan dan kelancaran kepada petugas dalam melakukan pekerjaannya.

\section{Kajian Pustaka}

Pada 1991, sekelompok insinyur SUN dipimpin oleh Patrick Naughton dan James Gosling ingin merancang bahasa komputer untuk perangkat konsumer seperti cable TV Box. Dikarenakan perangkat tersebut tidak memiliki banyak memori, bahasa harus berukuran kecil dan mengandung kode yang liat. Juga karena manufaktur manufaktur berbeda memilih processor 
yang berbeda pula, maka bahasa harus bebas dari manufaktur manapun.

Mulanya bahasa yang diciptakan diberi nama "Oak" oleh James Gosling yang mendapat inspirasi dari sebuah pohon yang berada pada seberang kantornya, namun dikarenakan nama Oak sendiri merupakan nama bahasa pemrograman yang telah ada sebelumnya, kemudian SUN menggantinya dengan JAVA. Nama JAVA sendiri terinspirasi pada saat mereka sedang menikmati secangkir kopi di sebuah kedai kopi yang kemudian dengan tidak sengaja salah satu dari mereka menyebutkan kata JAVA yang mengandung arti asal bijih kopi. Akhirnya mereka sepakat untuk memberikan nama bahasa pemrograman tersebut dengan nama JAVA.

Java adalah bahasa pemrograman yang berorientasi objek (OOP) dan dapat dijalankan pada berbagai platform sistem operasi. Perkembangan Java tidak hanya terfokus pada satu sistem operasi, tetapi dikembangkan untuk berbagai sistem operasi dan bersifat open source.

Sebagai sebuah peralatan pembangun, teknologi Java menyediakan banyak tools : compiler, interpreter, penyusun dokumentasi, paket kelas dan sebagainya.

Aplikasi dengan teknologi Java secara umum adalah aplikasi serba guna yang dapat dijalankan pada seluruh mesin yang memiliki Java Runtime Environment (JRE).

\section{METODE PELAKSANAAN}

Pelatihan dilakukan dihadapan guru-guru dan dirancang dalam dua kali pertemuan. Pertemuan pertama adalah wawancara mengenai kebutuhan fungsional dan non fungsional dari program aplikasi. Pertemuan kedua adalah pelatihan penggunaan aplikasi seleksi penerimaan siswa baru untuk para panitia penerimaan siswa baru di SMK Tanjung Barat dan SMK PGRI 28. Kegiatan pengabdian ini menggunakan metode presentasi, ceramah dengan teknik tanya jawab dan simulasi data pelatihan. Kemudian untuk mempermudah diberikan contoh dan dibuka kesempatan untuk tanya jawab bagi peserta pengabdian.

\section{Tahapan Rencana}

Adapun tahapan pelaksanaan program yaitu sebagai berikut :

1. Persiapan

Sebelum pelaksanaan pelatihan tentunya dilakukan persiapanpersiapan guna kelancaran pelatihan. Persiapan yang kami lakukan antara lain adalah:

a. Survei tempat pelaksanaan kegiatan.

b. Kegiatan pelatihan seleksi \& penerimaan siswa baru ini melibatkan semua panitia yang tentunya sudah mengetahui tentang teknologi dan penerapan aplikasi yang akan digunakan dalam pelatihan.

c. Jadwal pelatihan yang tentunya disesuaikan dengan agenda para panitia penerimaan siswa baru, terlebih dahulu dikoordinasikan dengan kedua belah pihak

d. Koordinasi dalam penyediaan fasilitas pelatihan seperti laptop dan Proyektor.

\section{Pelaksanaan Pelatihan}

Kegiatan pengabdian akan dilaksanakan setelah semua perizinan dan persiapan peralatan sudah selesai dilakukan, Kegiatan pengenalan dan pelatihan akan berbeda dengan kegiatan belajar mengajar pada umumnya. Kegiatan pelatihan akan dibuat semenarik mungkin, fun learning, dan selain belajar mereka juga akan diberi 
motivasi. Adapun pelaksanaan kegiatan yaitu sebagai berikut:

a. Pelatihan ini mencakup penggunaan aplikasi seleksi \& penerimaan siswa baru, mulai dari pencatatan data calon siswa baru, data registrasi siswa, seleksi kejurusan siswa, pembayaran siswa dan pembuatan laporan. Peserta pelatihan akan mengikuti semua kegiatan pelatihan.

b. Target quota kegiatan pelatihan ini adalah 5 peserta pelatihan untuk masing-masing sekolah yang merupakan guru SMK Tanjung Barat dan SMK PGRI 28, dan waktu pelatihan dilaksanakan pada bulan Juni 2017 dengan tanggal yang telah disepakati dengan pihak sekolah. Tempat pelatihan berlokasi di SMK Tanjung Barat dan SMK PGRI 28.

c. Fasilitas seperti laptop, papan tulis atau whiteboard dan Projector disediakan sesuai kebutuhan bisa dari pihak sekolah maupun dari kegiatan pelaksana

d. Evaluasi Pelatihan

Setelah pelatihan berakhir, tentunya perlu adanya evaluasi yang dilakukan untuk melihat sejauh mana perkembangan hasil yang didapatkan dari pelatihan apakah telah berjalan dengan baik atau belum sekaligus evaluasi kekurangan dari pelaksanaan. Selama kegiatan juga dilakukan pengamatan apakah tujuan dan target dari pelaksanaan pelatihan ini sudah tercapai untuk sekaligus membahas tentang kendalakendala yang mungkin ditemui dalam pelaksanaan.

\section{HASIL DAN PEMBAHANSAN}

\section{Kegiatan Pendahulu}

Pada bulan Maret 2017 Kepala SMK Tanjung Barat dan SMK PGRI 28 Jakarta telah memberikan izin dilaksanakannya kegiatan pengabdian masyarakat dengan tema "Pelatihan Seleksi Penerimaan Siswa Baru Pada SMK Tanjung Barat dan SMK PGRI 28 Menggunakan Bahasa Pemrograman Java"

Setelah mendapatkan izin dari pihak sekolah, kemudian kami mulai persiapan sistem dan membuat materi pelatihan sesuai dengan jumlah peserta yang akan datang mengikuti pelatihan. Dari data yang diperoleh, jumlah peserta yang akan mengikuti pelatihan ini sekitar 10 orang guru dari SMK Tanjung Barat dan SMK PGRI 28 Jakarta.

\section{Realisasi Kegiatan Abdimas}

Materi yang kami berikan adalah materi tentang pelatihan penggunakan aplikasi seleksi \& penerimaan siswa baru yang terdiri atas :

1. Mengenal dan memahami penggunaan awal dari aplikasi seleksi \& penerimaan siswa baru

2. Menginput, mencetak informasi dan membuat laporan siswa baru yang cepat dan akurat

Pelaksanaan kegiatan pelatihan dilakukan di dua tempat yang berbeda, diantaranya SMK Tanjung Barat \& SMK PGRI 28 dengan rincian kegiatan sebagai berikut :

Tabel 1 Jadwal Pelaksanaan Kegiatan Pelatihan di SMK Tanjung Barat

\begin{tabular}{|c|c|c|}
\hline $\begin{array}{c}\text { Hari / } \\
\text { Tanggal }\end{array}$ & Waktu & Kegiatan \\
\hline Sabtu, & 10.00 & Pembukaan \\
\cline { 2 - 3 } 3 juni & $10.30-$ & Pengenalan \\
2017 & 12.00 & Interface Dari \\
& & Menu-Menu \\
& & Pada Aplikasi \\
\hline
\end{tabular}




\begin{tabular}{|c|c|c|}
\hline \multirow{1}{*}{} & & $\begin{array}{c}\text { penerimaan } \\
\text { siswa baru }\end{array}$ \\
\cline { 2 - 3 } $\begin{array}{c}\text { Sabtu, } \\
10 \text { juni }\end{array} 2017$ & 12.00 & Penutupan \\
\cline { 2 - 3 } & 10.00 & Pembukaan \\
11.30 & $\begin{array}{c}\text { Pelatihan } \\
\text { penginputan } \\
\text { data } \\
\text { pendaftaran, } \\
\text { registrasi, } \\
\text { pembayaran, } \\
\text { percobaan tes } \\
\text { seleksi \& } \\
\text { cetak laporan }\end{array}$ \\
\cline { 2 - 3 } & 11.30 & Evaluasi \\
\cline { 2 - 3 } & 12.00 & Penutupan \\
\hline
\end{tabular}

Tabel 2 Jadwal Pelaksanaan Kegiatan Pelatihan di SMK PGRI 28 Jakarta

\begin{tabular}{|c|c|c|}
\hline $\begin{array}{c}\text { Hari / } \\
\text { Tanggal }\end{array}$ & Waktu & Kegiatan \\
\hline \multirow{3}{*}{$\begin{array}{l}\text { Sabtu, } \\
3 \text { juni } \\
2017\end{array}$} & 14.00 & Pembukaan \\
\hline & $\begin{array}{c}14.30- \\
16.00\end{array}$ & $\begin{array}{c}\text { Pengenalan } \\
\text { Interface Dari } \\
\text { Menu-Menu } \\
\text { Pada Aplikasi } \\
\text { penerimaan } \\
\text { siswa baru }\end{array}$ \\
\hline & 16.00 & Penutupan \\
\hline \multirow{4}{*}{$\begin{array}{l}\text { Sabtu, } \\
10 \text { juni } \\
2017\end{array}$} & 14.00 & Pembukaan \\
\hline & $\begin{array}{c}14.10- \\
15.30\end{array}$ & $\begin{array}{c}\text { Pelatihan } \\
\text { penginputan } \\
\text { data } \\
\text { pendaftaran, } \\
\text { registrasi, } \\
\text { pembayaran, } \\
\text { percobaan tes } \\
\text { seleksi \& } \\
\text { cetak laporan }\end{array}$ \\
\hline & 15.30 & Evaluasi \\
\hline & 16.00 & Penutupan \\
\hline
\end{tabular}

Kegiatan pelatihan ini mencakup cara penggunaan aplikasi seleksi \& penerimaan siswa baru, mulai dari pencatatan data calon siswa baru, data registrasi siswa, seleksi kejurusan siswa, pembayaran siswa dan pembuatan laporan. Setelah diadakannya kegiatan berupa pelatihan penggunaan aplikasi seleksi \& penerimaan siswa baru kepada para guru-guru SMK Tanjung Barat dan SMK PGRI 28 Jakarta, para peserta sangat antusias dalam menerima pelatihan tersebut. mereka memahami \& mengerti akan manfaat yang sangat besar \& kemudahan yang bisa didapat dari penggunaan aplikasi tersebut untuk membantu proses penerimaan siswa baru. Demonstrasi penggunaan aplikasi yang telah disampaikan oleh pembicara pelatihan ini membuat mereka memahami cara penggunaan aplikasi tersebut \& mampu menerapkannya pada saat penerimaan siswa baru disekolah mereka nanti.

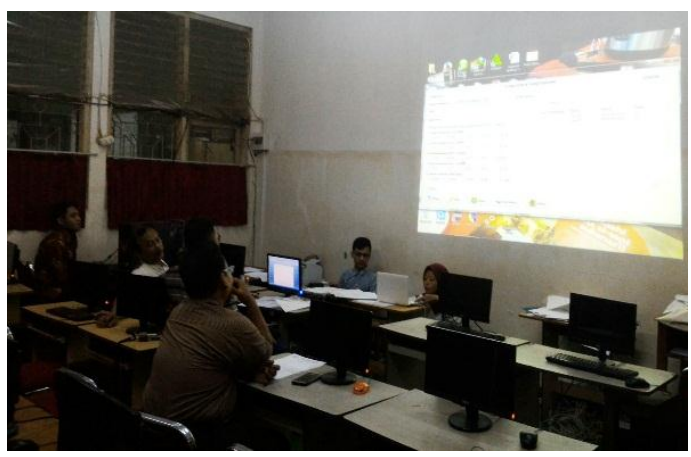

Gambar 1. Pelatihan SMK Tanjung Barat

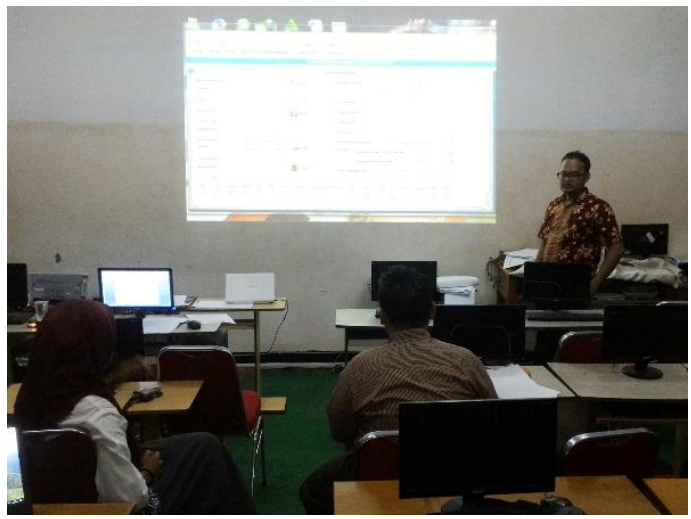

Gambar 2. Pelatihan SMK Tanjung Barat

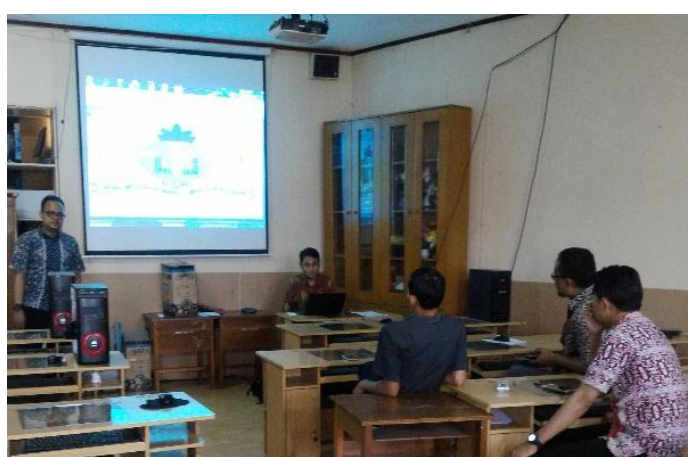

Gambar 3. Pelatihan SMK PGRI 28 Jakarta 


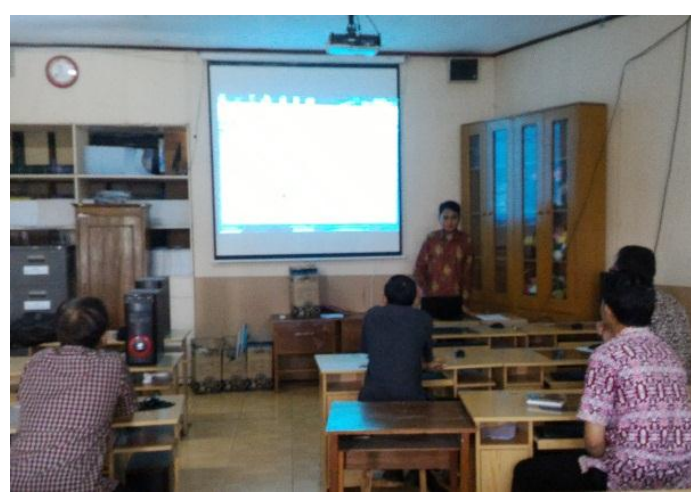

Gambar 4. Pelatihan SMK PGRI 28 Jakarta

Pelatihan pengabdian masyarakat ini pun menghasilkan luaran berupa aplikasi program yang digunakan dalam pelatihan penyeleksian penerimaan siswa baru dengan tampilan sebagai berikut :

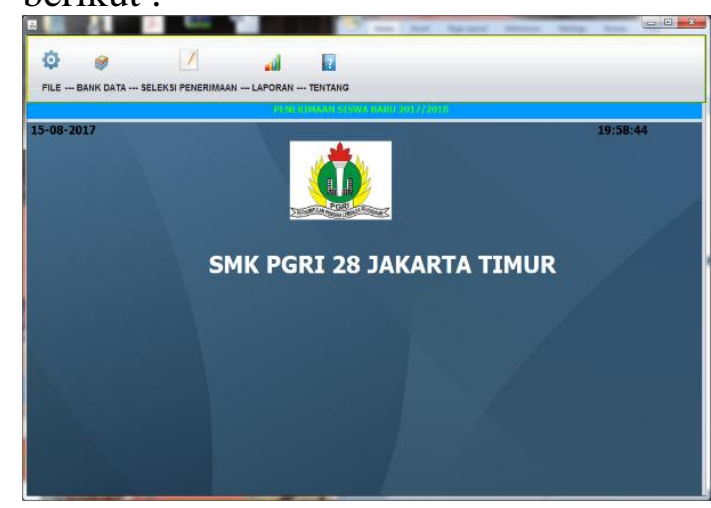

Gambar 5. Tampilan Aplikasi

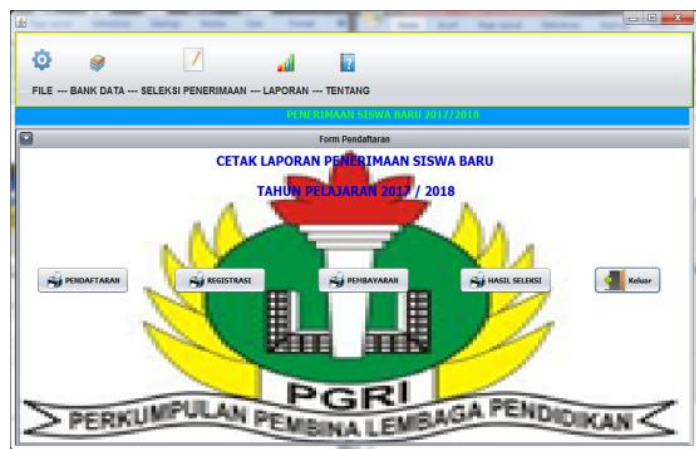

Gambar 6. Tampilan laporan aplikasi

\section{Hasil Pelaksanaan}

Pelatihan yang diikuti oleh 10 peserta yang terdiri dari 5 guru di SMK Tanjung Barat \& 5 guru di SMK PGRI 28 Jakarta ini memberikan wawasan sekaligus keahlian tambahan kepada peserta atas pemanfaatan aplikasi seleksi $\&$ penerimaan siswa baru.

Berdasarkan pelatihan yang telah dilaksanakan diperoleh hasil sebagai berikut:

1. Aplikasi penerimaan siswa baru yang dirancang menggunakan bahasa pemrograman Java dapat membantu panitia dalam menyeleksi \& penerimaan siswa baru .

2. Penggunaan aplikasi untuk mengelola data pendaftaran calon siswa baru, registrasi siswa baru, seleksi kejurusan, pembayaran dan laporan siswa baru.

3. Panitia seleksi penerimaan siswa baru mampu menggunakan program aplikasi penerimaan siswa baru dengan baik.

4. Meningkatkan kemampuan guru dalam hal pemanfaatan teknologi komputer untuk pengolahan data penerimaan siswa baru.

5. Pengelolaan data-data penerimaan siswa baru dapat terorganisir dengan baik serta cepat dan menghasilkan informasi dan laporan yang akurat dengan mudah.

\section{SIMPULAN}

Berdasarkan rumusan masalah, dan pembahasan pada penelitian ini, maka dapat disimpulkan Sistem penerimaan siswa baru yang sedang berjalan pada SMK Tanjung Barat dan SMK PGRI 28 Jakarta masih menggunakan Microsoft Excel. Pencatatan data pendaftaran calon siswa baru, registrasi siswa baru, seleksi kejurusan siswa baru, pembayaran serta pembuatan laporan masih dicatat dalam file Excel sehingga tim pelaksana mengusulkan mengadakan pelatihan penerapan sistem aplikasi seleksi \& penerimaan siswa baru yang dirancang menggunakan bahasa pemrograman java 
yang mampu membantu mempermudah para guru dalam mengelola data seleksi \& penerimaan siswa baru setelah diadakannya pelatihan penggunaan aplikasinya. Aplikasi yang diterapkan mampu mengelola data, menghasilkan informasi dan pembuatan laporan yang cepat serta akurat.

Berdasarkan hasil pelaksanaan dapat diajukan beberapa saran sebagai diantaranya Pemanfaatan aplikasi diharapkan dapat dikembangkan kembali dengan beberapa fitur-fitur baru yang disesuaikan dengan kebutuhan lainnya oleh pihak disekolah serta pihak sekolah disarankan untuk selalu memonitoring penggunaan aplikasi ini, selalu Backup data secara berkala untuk mencegah hal-hal yang tidak diinginkan seperti kerusakan sistem atau perangkat keras yang mengakibatkan kehilangan data.

\section{DAFTAR PUSTAKA}

Daryanto. (2010). Panduan
Pembelajaran
Inovatif. Jakarta:Publisher.

Hariyanto, B. (2012). Esensi - Esensi Bahasa Pemrograman Java: Revisi. Keempat. Bandung : Informatika.

Huda, M. (2010). Membuat Aplikasi Data Base Dengan Java, MySQL dan Netbeans. Jakarta : PT Elex Media Komputerindo

Iskandar, D. (2011). Perancangan Sistem Penerimaan Mahasiswa Baru Politeknik Sukabumi Berbasis WEB. Diakses dari http://elib.unikom.ac.id/gdl.php? $\underline{\bmod =\text { browse \&op }=\text { read\&id=jbptu }}$ nikompp-gdl-decyskan-25186

Jogiyanto, H.M., (2005). Analisa dan Desain Sistem Informasi: Pendekatan. Terstruktur Teori dan Praktik Aplikasi Bisnis, Yogyakarta : ANDI.

Mardiani, E. (2008). Panduan Java Netbeans. Yogyakarta: ANDI.

Wahyudi, D. (2010). Teknologi Informasi dan Komunikasi. Pusat Pembukuan Kementrian Pendidikan Nasional. Jakarta. 